\title{
Recovery: The Salvation of Desecheo National Wildlife Refuge
}

\author{
Ted Williams
}

Godn ood news is scarce in Puerto Rico these days. But if you Ilook 13 miles to the west, on a 358-acre island called Desecheo, you'll find a mother lode.

Desecheo, once the Caribbean's most important Brown Booby breeding habitat, was made a national wildlife refuge in 1976. This was something of a futile gesture because invasive aliens — Black Rats, feral goats and Macaque Monkeys — had extirpated the Brown Boobies (which once numbered around $10,000)$ along with the seven other nesting sea-bird species. The invasive species also blighted forests and the federally threatened
Higo Chumbo Cactus, and reduced native land birds, reptiles, and invertebrates to a shadow of their former abundance.

Desecheo was an ecological wasteland.

In 1976 there was virtually nothing the U.S. Fish and Wildlife Service could do about that. But in 1994 it acquired a powerful ally with the founding of Island Conservation (IC), a nonprofit team of biologists dedicated to preventing extinctions around the globe. There was and is no shortage of work.

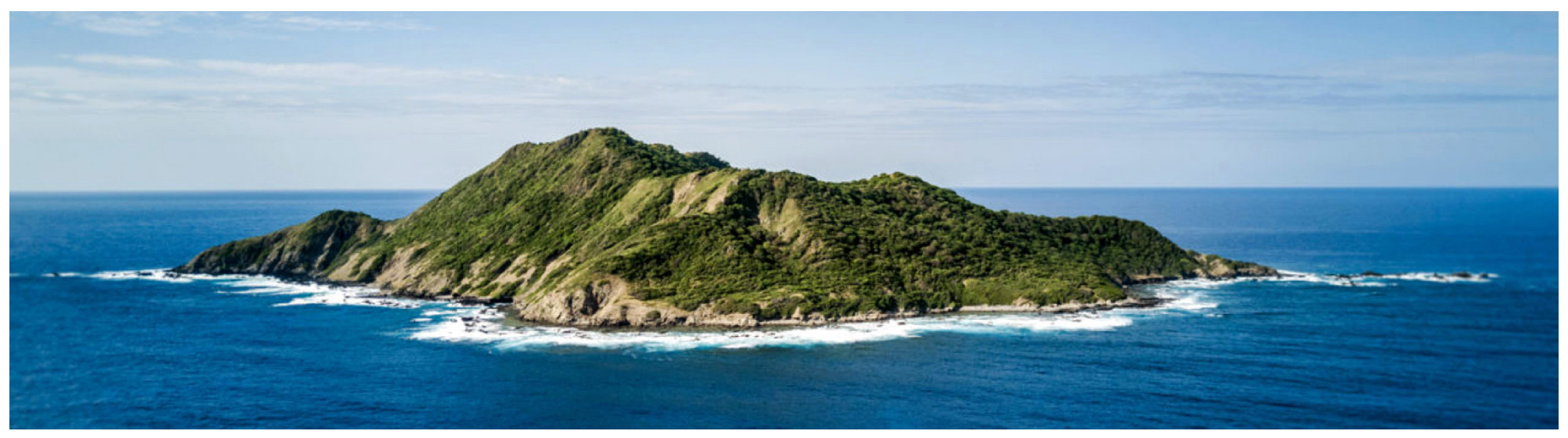

Isla Desecheo, Puerto Rico. Photograph (C Claudio Uribe, Island Conservation.

This article first appeared on 6 November 2017 in "Cool Green Science," the conservation science blog of The Nature Conservancy (https:// blog.nature.org/science/2017/11/06/ recovery-the-salvation-of-desecheonational-wildlife-refuge/?src=e.cgs).

"Recovery: The Salvation of Desecheo National Wildlife Refuge" (text (C) 2017 Ted Williams; images (C) Island Conservation); reprinted with permission (scientific names of the herpetofauna added).

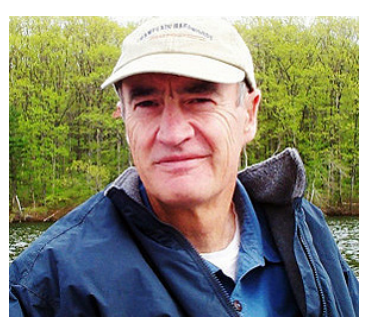

Ted Williams detests baseball, but is as obsessed with fishing as was the "real" (or, as he much prefers, "late") Ted Williams. What he finds really discouraging is when readers meet him in person and still think he's the frozen ballplayer. The surviving Ted writes full time on fish and wildlife issues. In addition to freelancing for national publications, he serves as Conservation Editor for Fly Rod \& Reel where he contributes a regular feature-length column.

This past June Williams was recognized by the Outdoor Writers Association of America (OWAA) as the nation's best outdoor columnist for his work in Audubon magazine. He has also received numerous other national writing and conservation awards. He lives in Grafton, Massachusetts. 


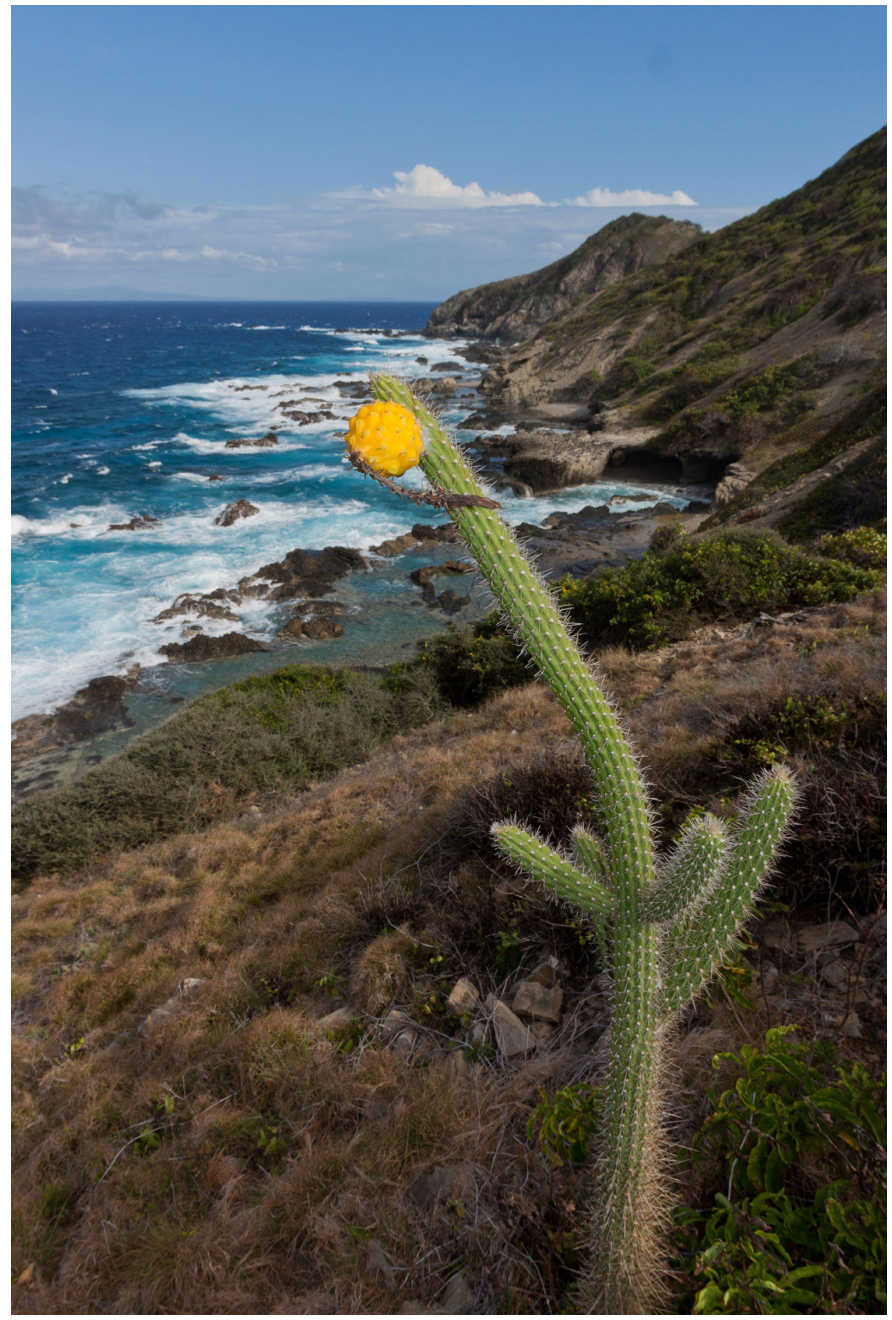

Higo Chumbo by the coast, Isla Desecheo. Photograph (C) Island Conservation.

Although islands comprise a miniscule fraction of Earth's landmass they harbor about half of all endangered species. At least 80 percent of the 245 recorded animal extinctions since 1500 have occurred on islands.

IC and multiple partners (frequently The Nature Conservancy) have thus far removed invasive mammals from 59 islands thereby benefitting 1,090 populations of 402 native species and subspecies. Research just released by IC, Birdlife International, the International Union for Conservation of Nature, and the University of California at Santa Cruz demonstrates that 41 percent of the planet's vertebrates threatened with extinction can be saved by ridding certain islands of invasive mammals.

Last July, after an exhausting, expensive ten-year battle, IC and its partners certified that Desecheo National Wildlife Refuge was free of Macaques (if you don't count a single, aging female) and rats. The last feral goat was removed in 2009.

Such successes were impossible before the advent of recent technology including: the anticoagulant rodenticide

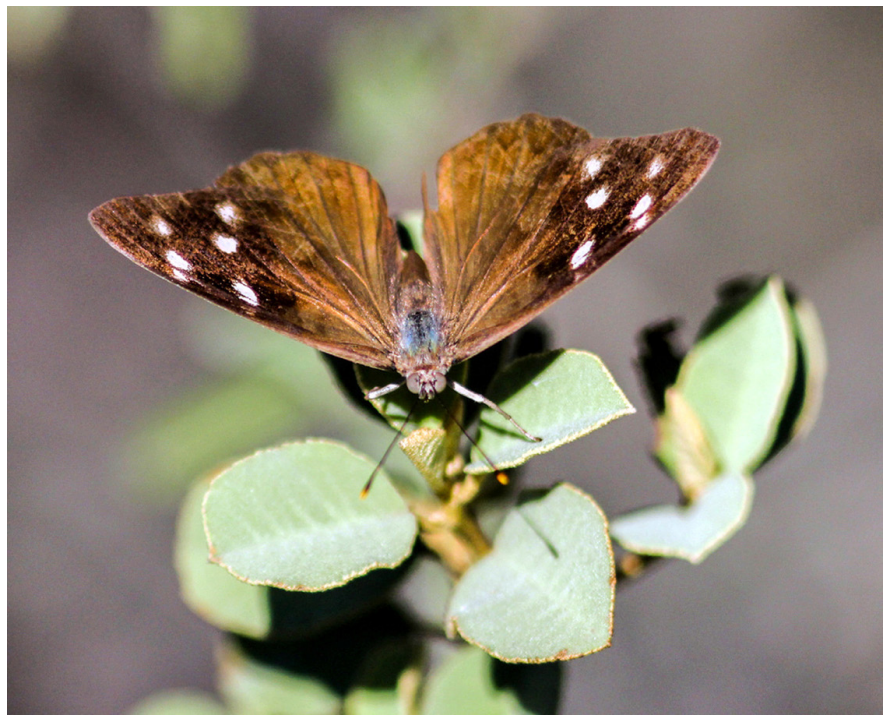

Desecheo butterfly. Photograph (C) Armando Feliciano, Island Conservation.

brodifacoum, sufficiently fast acting to kill rats before they learn to avoid it; thermal imaging which allows partners to detect alien mammals at night and in forest canopies; GIS (Geographic Information System) for recording precise positions on Earth's surface so that rodenticide-laced bait can be applied to every part of an island; and satellite imaging to determine when islands lose greenery so eradications can happen when less food is available to aliens.

Even with goats (introduced in 1788) and rats (introduced circa 1900) a few sea birds hung on. What finally did them in were the Macaques, unleashed in 1966 for medical research by the then clueless National Institutes of Health.

Ecological Illiteracy Leads to Ecological Wastelands The most formidable obstacle confronting IC and partners is ecological illiteracy. They get savaged by chemophobes who fear and loathe all poisons in all situations and by animalrights types who defend alien wildlife, rats included, and

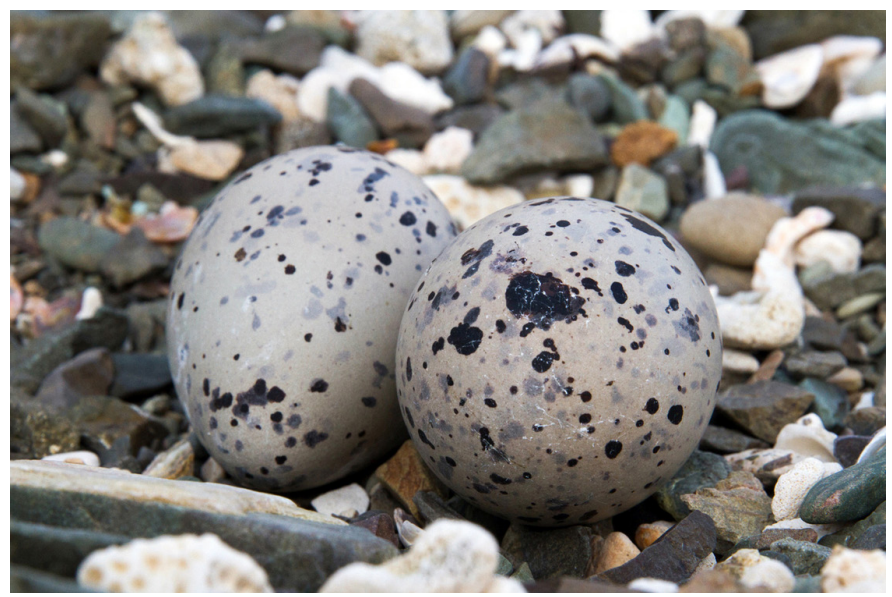

Desecheo bird eggs. Photograph (c) Claudio Uribe, Island Conservation. 
decry the often unavoidable, increasingly minor, and always inconsequential bykill of non-target wildlife.

The Desecheo project, however, proceeded unopposed. It wasn't as if Puerto Ricans are more enlightened than other Americans. It's just that they live in an alien-infested hell of Macaques that tear up their gardens and bite them, exposing them to the herpes B virus (relatively harmless to Macaques but usually fatal to humans); feral hogs and feral goats, which also tear up their gardens; feral cats, which infect them and wildlife with toxoplasmosis; and a biblical plague of rats and House Mice.

Public reaction was different at Channel Islands National Park off southern California. When IC and partners set about saving and restoring a host of native species including the endangered Ashy Storm-petrel, imperiled Scripps's Murrelet, Cassin's Auklet, and Anacapa Deer Mouse by eradicating Black Rats, they were delayed by litigation. Typical commentary in the local press included: "Species go extinct all the time" and "Who are humans to call other species invasive?" Park rangers were obliged to wear bulletproof vests; and shortly before the first bait application, two men landed on Anacapa Island in an inflatable boat and started flinging pellets of vitamin $\mathrm{K}$ - brodifacoum's antidote.

Had Anacapa been infested with Macaques, recovery would have been a political impossibility.

Prudently, IC doesn't talk it up about how it, the USDA's Wildlife Services, and a nonprofit group called White Buffalo removed Macaques from Desecheo. But it's important for the public to understand just how difficult and heroic was this effort, a first in island recovery. Learning as they worked, the partners first tried baiting and trapping. It failed. They had

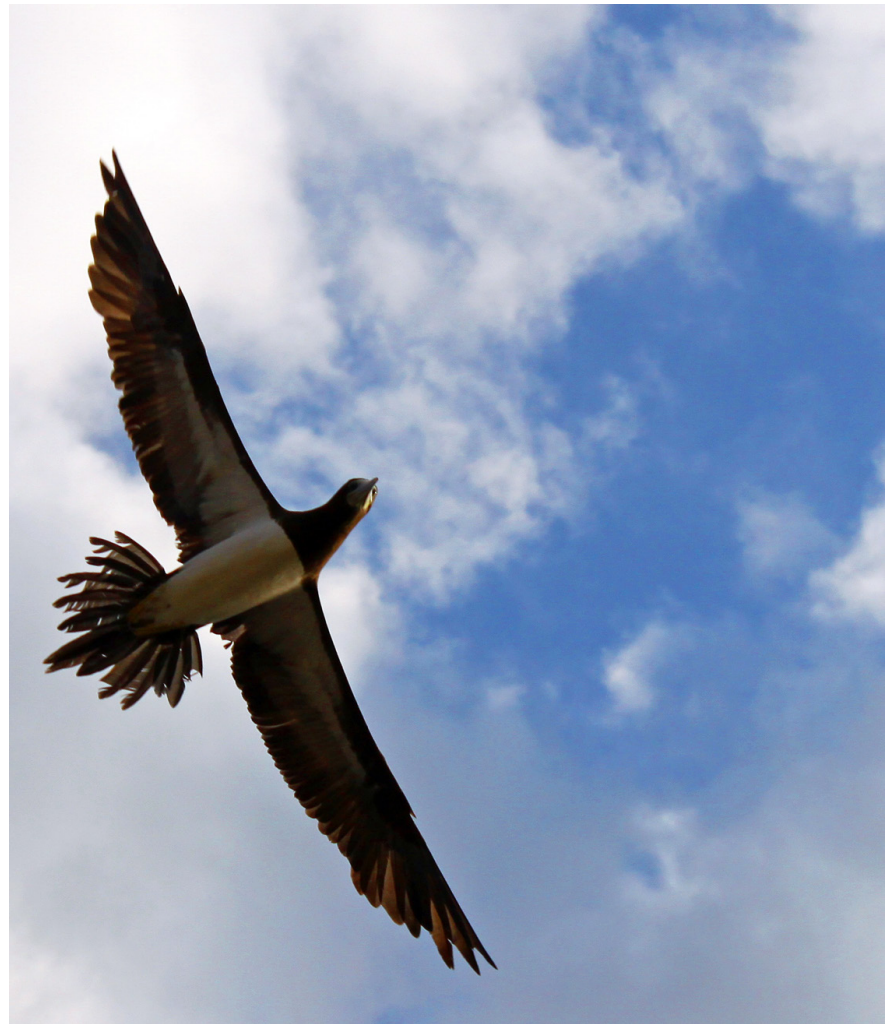

Brown Booby (Sula leucogaster), Isla Desecheo. Photograph (C) Island Conservation.

better results with rifles but had to bring in thermal-imaging equipment when the Macaques retreated to the forest canopy.

"It was a hell hole," recalls White Buffalo's president, Dr. Anthony DeNicola. "Ninety or 100 degrees with no place to get out of the sun."

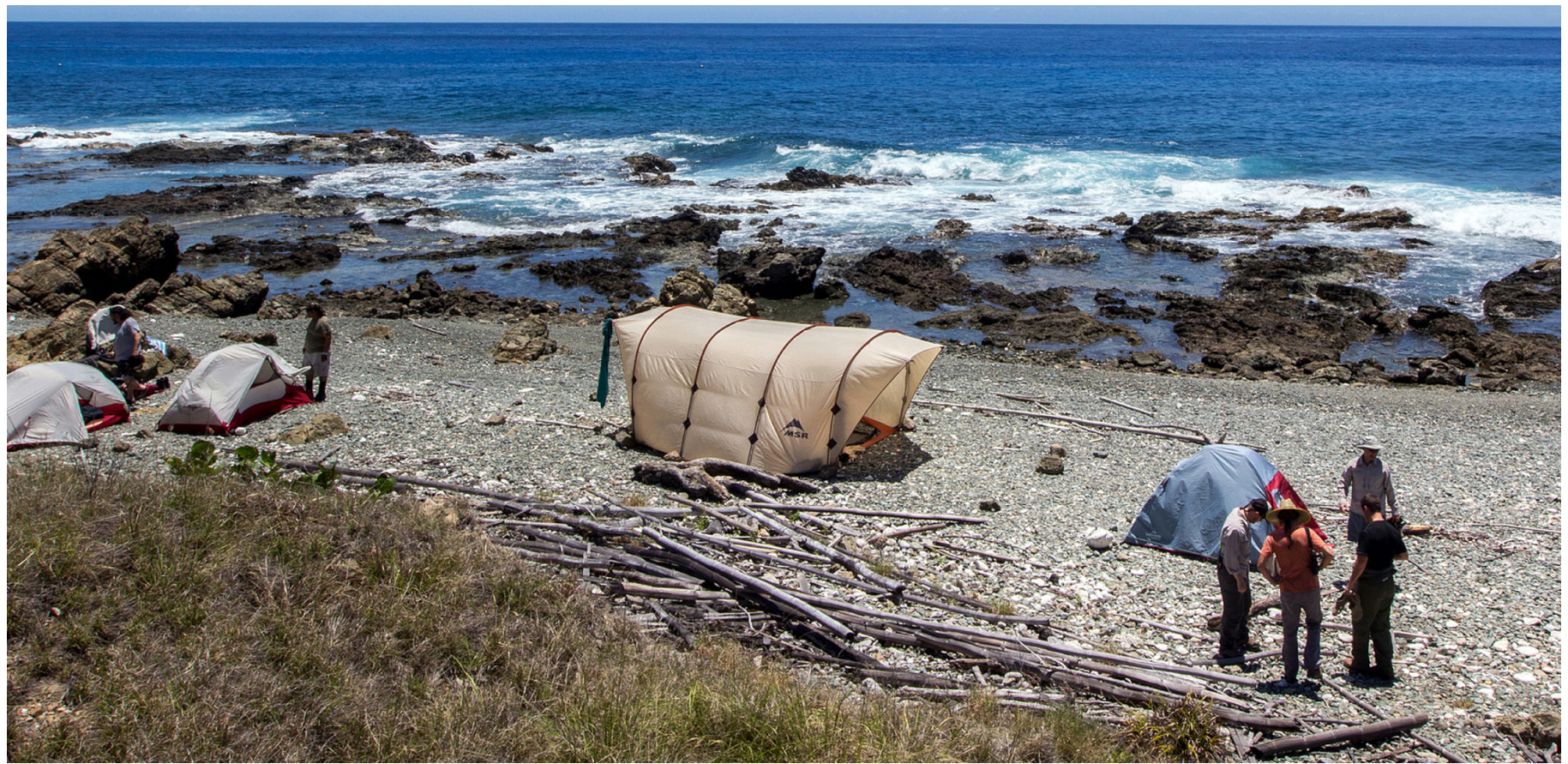

Desecheo beach camp. Photograph (C) Claudio Uribe, Island Conservation. 


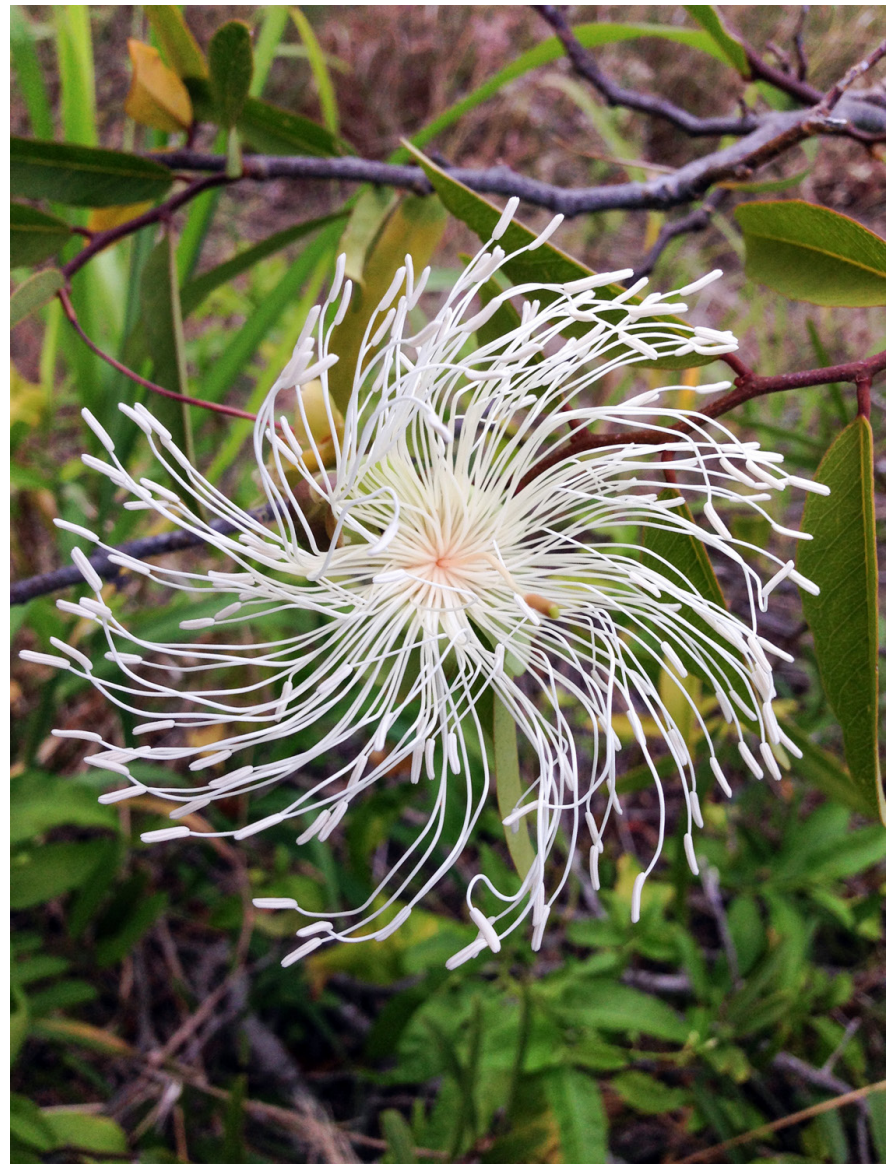

Desecheo flower. Photograph (C) Armando Feliciano, Island Conservation.
IC and White Buffalo staffers would sit for 14 hours a day, scanning trees and terrain with binoculars. Toward the end it would take them a month to take out one or two monkeys. Finally they had to bring in tagged, sterilized "Judas animals" from Puerto Rico to socialize with the few remaining wild ones and reveal their presence. It took five years to finish the job.

\section{Safe for Birds Again}

The reluctance of IC to offer such details in its press releases and interviews doesn't mean it tries to fly under the radar. "That would be inconsistent with our values," remarks Heath Packard, IC's director of government and public relations. It would also be illegal under the National Environmental Policy Act, which requires IC and its federal partners to engage with the public, disclosing alternatives and their various consequences.

"The outreach is always the same," says IC's global affairs director, Gregg Howald. "It's just that results of that outreach vary widely from location to location."

Citing the Polynesian Rat eradication on Lehua Island off Hawaii, completed September 13, Howald offers this: "For years we'd been reaching out to the community with blog postings, talking with people, and holding public meetings. It wasn't until late July that a few vocal individuals realized this was really going to happen and started trying to stop it, making lots of noise and drawing media attention. It was just off the rails. We had a public meeting in which people yelled

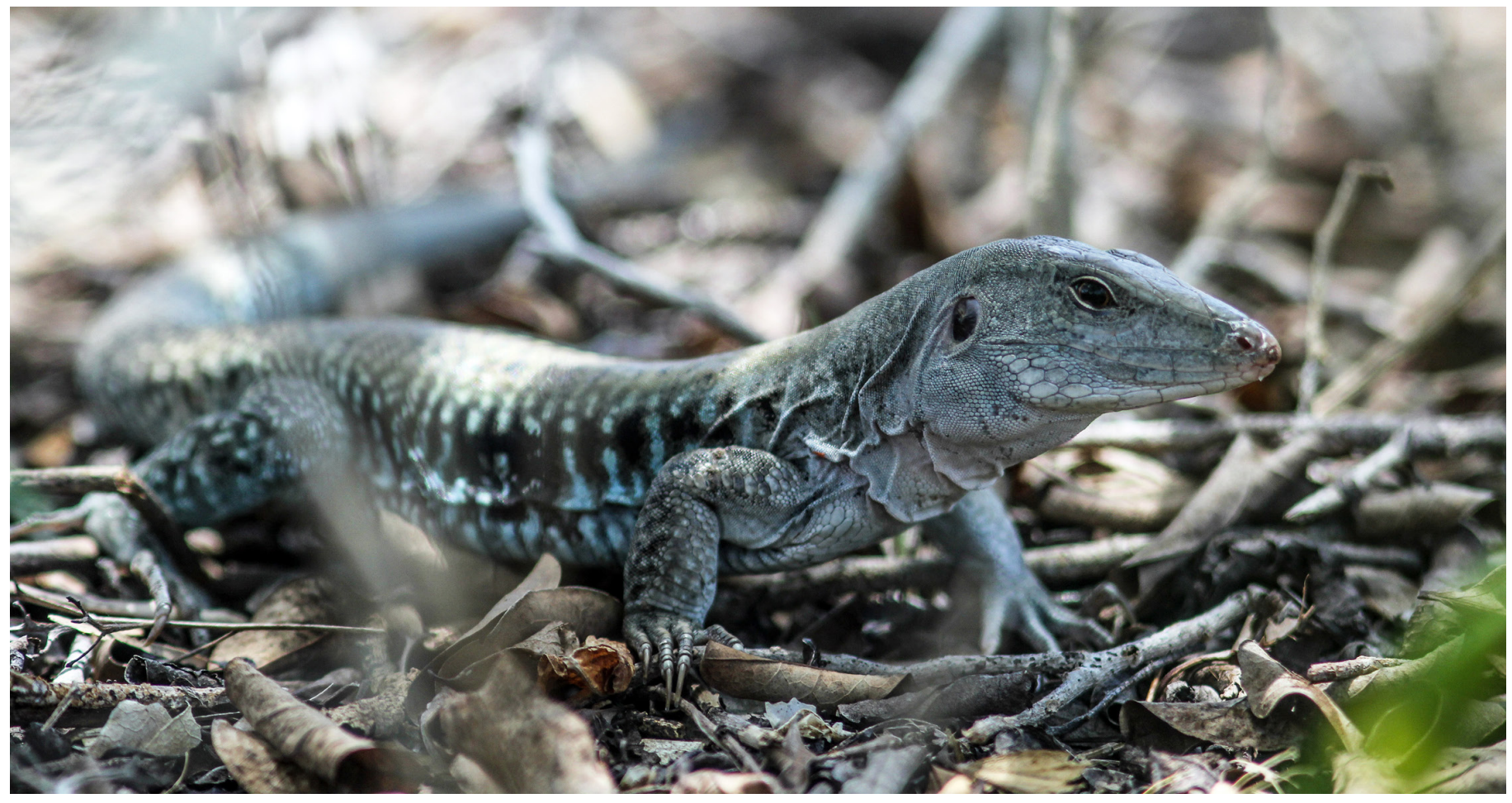

Male endemic Desecheo Ground Lizard (Pholidoscelis desechensis), Isla Desecheo. Photograph (C) Armando Feliciano, Island Conservation. 
at us for over two hours. It was horrible. Despite all our outreach, we wound up with a confrontation that started a cascade of anti-project misinformation."

For example, the Huffington Post ran an op-ed by one Maggie Sergio (whom it identified as a "writer, conservationist and concerned citizen of the planet") suggesting that five Pilot Whales, which later beached themselves on Kauai and died (as they commonly do everywhere they exist) were victims of diphacinone - an impossibility. Sergio also claimed that "three aerial poison drops, totaling 11.5 tons of diphacinone" were delivered by helicopter. There isn't enough diphacinone in the world to drop 11.5 tons. What was dropped was 8.5 tons of bait of which .005 percent was diphacinone. This and other misinformation was recycled by local media.

It was exactly this sort of fear mongering that motivated the partners to use diphacinone, less toxic and therefore less effective than brodifacoum. But apparently it worked. "So far so good," says Howald. All the rats we collared and monitored died. It will take time to tell for sure [if the project succeeded]. We did state in our environmental assessment that if diphacinone failed, we could come back in with brodifacoum."

Either way Lehua Island will again be safe for federally threatened Newell's Shearwaters, Band-rumped Stormpetrels (now a candidate for Endangered Species Act protection), Wedge-tailed Shearwaters, Brown Boobies, Red-footed Boobies, Laysan Albatrosses, Black-footed Albatrosses, Christmas Shearwaters, Bulwer's Petrels, Red-tailed Tropicbirds, and Black Noddies.

\section{Spectacular Results}

Recovery of Desecheo's native ecosystem is just beginning, but already results are spectacular. Despite insect surveys beginning in 1914 Dingy Purplewing Butterflies had never been observed on the island. In April their caterpillars were so abundant they defoliated Almacigo Trees (leaves quickly regenerated).

Endemic reptiles are doing much better, particularly Desecheo Anoles (Anolis desechensis), Desecheo
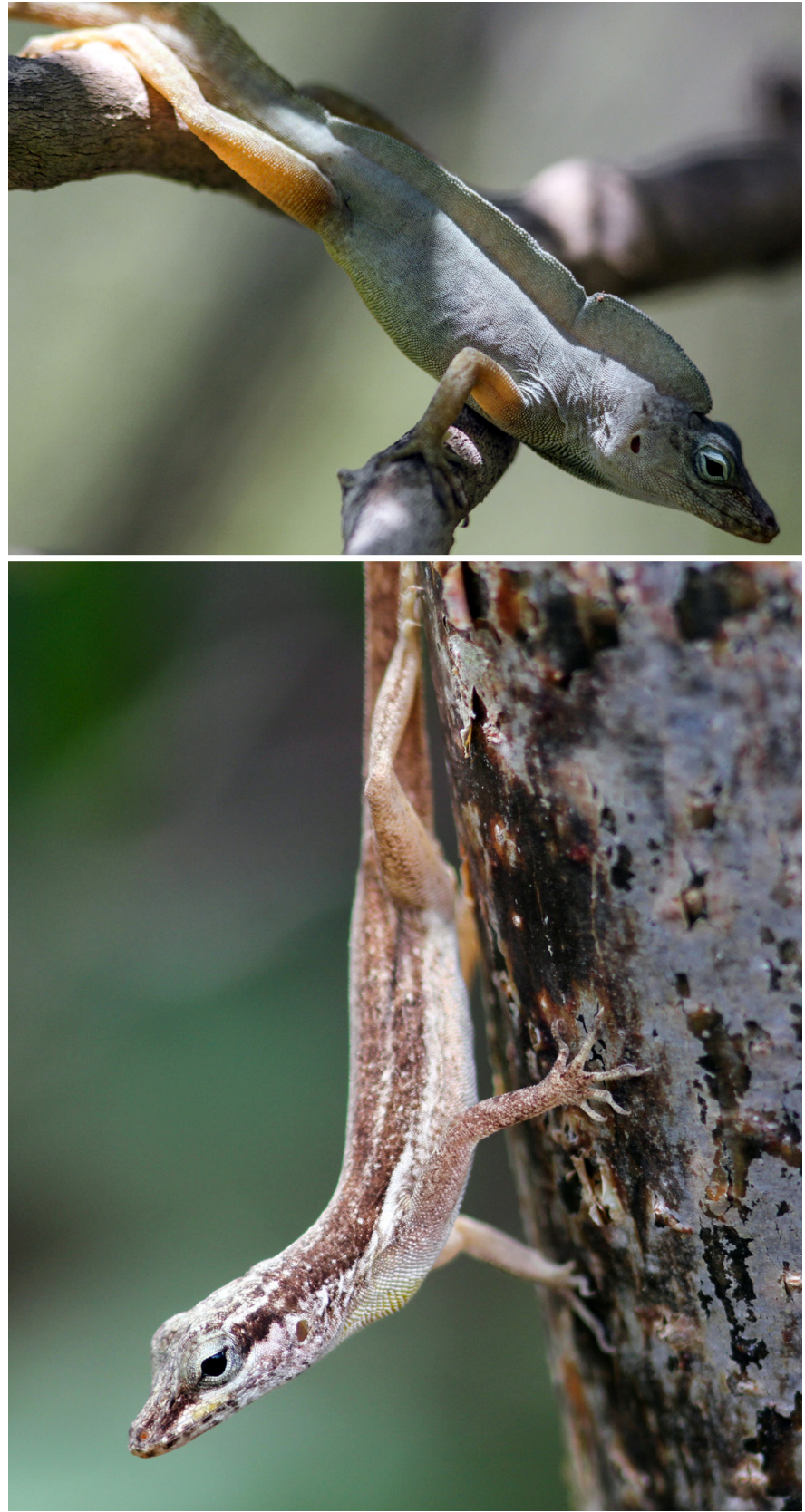

Male (top) and female endemic Desecheo Anoles (Anolis desechensis), Isla Desecheo. Photographs (C) Armando Feliciano, Island Conservation.

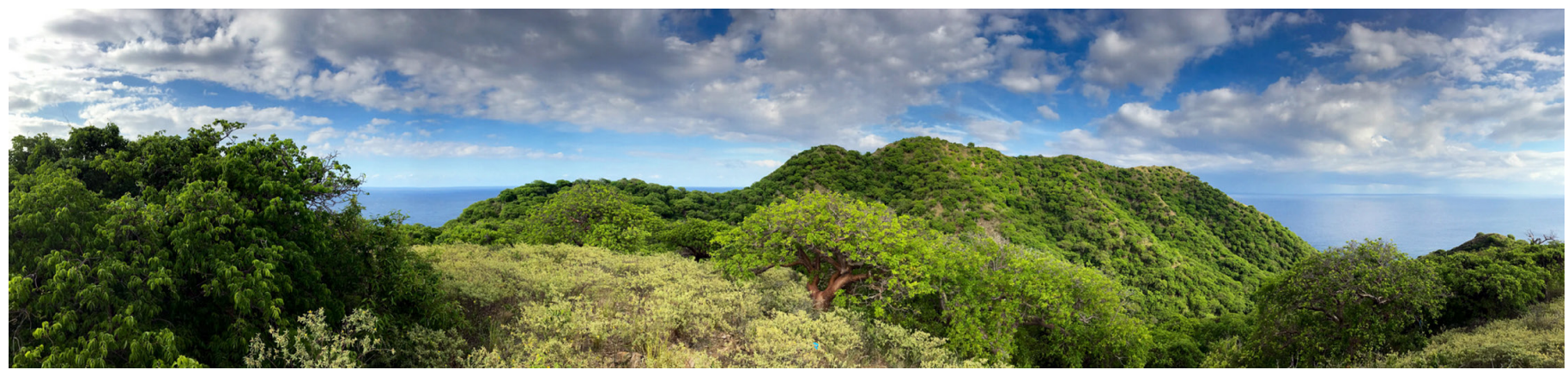

Desecheo panorama. Photograph (C) Heath Packard, Island Conservation. 
Ameivas (Pholidoscelis desechensis), and Puerto Rican Racer Snakes (Boridenophis portoricensis). A Puerto Rican Skink (Spondylurus nitidus), a species rarely observed in the past, has been sighted. Invertebrate density has increased. Native fruit trees and flowers are suddenly flourishing. New leaves, preferred by goats, rats, and Macaques, are more abundant than in anyone's memory. Higo Chumbo Cacti are rapidly recovering; and forests, particularly understories, appear to be growing faster.

At this writing no one has visited the island since the hurricanes, but there are no refuge buildings on Desecheo; and in the tropics vegetation bounces back quickly. As of midOctober there were new leaves and blooms on Puerto Rico.
In its island-hopping war against introduced aliens IC builds on each victory. "One thing I've learned is that you can get so focused on individual projects you start to lose sight of the forest for the trees," remarks Howald. "Now that we've had this success what does it mean? What's the potential of Desecheo; what's the leverage?"

The potential and leverage, he explains, is demonstration to regulatory agencies, the funding community, and especially the public: that the choice is salvation of nearly half the world's endangered species or the continued presence of alien invasives; that we can't have both; that if we want the former, we have to take out the latter; and that we can do that without risk to humans or native wildlife populations. 